\title{
PENGGUNAAN ALAT PERAGA SUMPIT UNTUK MENINGKATKAN HASIL BELAJAR MATEMATIKA KELAS XII MIPA 2 SMAN 1 PANGKALAN KERINCI
}

\author{
Risnita \\ Guru Matematika SMAN 1 Pangkalan Kerinci-Pelalawan \\ risnitamath@gmail.com
}

\begin{abstract}
ABSTRAK. Penelitian ini berawal dari rendahnya hasil belajar matematika peserta didik. Hal ini terlihat pada ulangan harian peserta didik yang berada di bawah Kriteria Ketuntasan Minimal (KKM). Salah satu penyebabnya adalah rendah pemahaman konsep matematika. Pemahaman konsep yang rendah disebabkan materi matematika masih dirasakan abstrak oleh peserta didik. Konsep matematika yang abstrak bagi peserta didik akan menjadi mudah dipahami apabila pembelajaran menggunakan alat peraga. Pembelajaran yang dilaksanakan adalah pembelajaran langsung menggunakan alat peraga sumpit. Penelitian ini bertujuan untuk mengetahui peningkatan hasil belajar peserta didik kelas XII MIPA 2 SMAN 1 Pangkalan Kerinci dan dilakukan dalam dua siklus yang terdiri dari perencanaan, pelaksanaan tindakan, pengamatan dan refleksi. Data penelitian yang dikumpulkan adalah data hasil belajar dan catatan lapangan. Data yang terkumpul dianalisis secara deskriptif. Hasil penelitian ini menunjukkan bahwa penerapan model pembelajaran pembelajaran langsung menggunakan alat peraga sumpit dapat meningkatkan hasil belajar. Peningkatan hasil belajar untuk KD 3.1 sebesar 22,58 $\%$ atau mencapai 96,77\% peserta didik yang berada di atas KKM. Sedangkan untuk KD 4.1 peningkatan dari siklus I ke siklus II sebesar $22,58 \%$ atau mencapai $93,55 \%$ peserta didik berada di atas KKM.
\end{abstract}

Kata kunci : Hasil belajar, Model pembelajaran Langsung dan Alat Peraga Sumpit 


\title{
THE USE OF CHOPSTICK TO IMPROVE THE MATHEMATICS LEARNING OUTCOMES OF THE STUDENTS OF CLASS XII MIPA SMAN 1 PANGKALAN KERINCI
}

\begin{abstract}
This research starts from the low results of learning mathematics students. This can be seen in the daily test of students who are below the Minimum Completion Criteria (KKM). One reason is a low understanding of mathematical concepts. Low understanding of concepts is due to the fact that mathematics is still abstracted by students. Abstract mathematical concepts for students will be easily understood when learning using teaching aids. Learning carried out is direct learning using chopstick props. This study aims to determine the improvement in learning outcomes of students of class XII MIPA 2 SMAN 1 Pangkalan Kerinci and carried out in two cycles consisting of planning, action, observation and reflection. The research data collected is data on learning outcomes and field notes. The collected data was analyzed descriptively. The results of this study indicate that the application of direct learning models using chopstick props can improve learning outcomes. Increased learning outcomes for KD 3.1 amounted to $22.58 \%$ or reached $96.77 \%$ of students who were above the KKM. While for KD 4.1 the increase from cycle I to cycle II is $22.58 \%$ or reaches $93.55 \%$ of students are above the KKM.
\end{abstract}

Keywords : Learning outcomes, Direct learning models, Sumpit Props.

\section{PENDAHULUAN}

Perkembangan teknologi dari tahun ketahun terus meningkat sesuai dengan tuntutan zaman.Karena tuntutan zamanlah mendorong manusia untuk lebih kreatif dalam mengembangan atau menerapkan teknologi.Pemikiran kreatif ini diperlukan pemahaman konsep matematika yang benar.Matematika merupakan ilmu dasar untuk menguasai teknologi.Matematika adalah salah satu media melatih kemampuan berfikir dan pemecahan masalah. Sebagaimana Peraturan Menteri Pendidikan Nasional Republik Indonesia No.22 tentang BSNP (2006) disampaikan bahwa tujuan mata pelajaran matematika adalah agar peserta didik memiliki kemampuan sebagai berikut: 
1)Memahami konsep matematika, menjelaskan keterkaitan antar konsep dan mengaplikasikan konsep atau algoritma, secara luwes, akurat, efisien, dan tepat dalam pemecahan masalah.

2)Menggunakan penalaran pada pola dan sifat, melakukan manipulasi matematika dalam membuat generalisasi, menyusun bukti, atau menjelaskan gagasan dan pernyataan matematika.

3)Memecahkan masalah yang meliputi kemampuan memahami masalah, merancang model matematika, menyelesaikan model dan menafsirkan solusi yang diperoleh.

4)Mengkomunikasikan gagasan dengan simbol, tabel, diagram, atau media lain untuk menjelaskan keadaan atau masalah.

5)Memiliki sikap menghargai kegunaan matematika dalam kehidupan yaitu memiliki rasa ingin tahu, perhatian dan minat dalam mempelajari matematika, serta sikap ulet dan percaya diri dalam pemecahan masalah.

Berdasarkan tujuan matematika sebagai fokus utama, kemampuan berpikir dengan pemahaman konsep matematika yang benar agar dapat memecahkan masalah matematika.Pemahaman kosep dalam matematika itu adalah bagian yang sangat dasar dan penting. Jika peserta didik memahami konsep matematika dengan benar, maka akan memudahkan mereka untuk menyelesaikan masalah yang berkaitan dengan matematika.

Pembelajaran matematika harus mampu mendorong peserta didik untuk mengembangakan kemampuan berfikir. Kenyataan dalam pembelajaran di kelas, yang ditemukan anak diarahkan pada kemampuan cara menggunakan rumus, menghapal rumus. Pembelajaran matematika hanya berfokus pada mengerjakan soal-soal rutin.Perserta didik jarang diajarkan bagaimana memahami konsep matematika, sehingga matematika tidak dapat digunakan untuk menyelesaikan masalah matematika yang berbeda dari soal latihannya. Contoh penggunaan matematika dalam kehidupan sehari-hari, yaitu "Firman akan menghiasi akuariumnya yang berbentuk balok dengan ukuran $120 \mathrm{~cm}$ x $120 \mathrm{~cm}$ x $50 \mathrm{~cm}$. Hiasan digantung pada kawat yang dihubungkan dari pojok atas akuarium ke pojok bawah akuarium. Agar hiasan berguna sebagai mainan untuk ikan2nya, maka panjang kawat minimal yang dibutuhkan Firman adalah..." kemungkinan jawaban ada 2 yaitu: (1) menghubungkan kawat pada pojok pada sisi dinding dan (2) menghubungkan kawat pada pojok dalam ruang. Pastilah cara kedua yang benar karena, jika didalam ruang maka hiasan yang digantung akan berguna sebagai mainan untuk ikan-ikan Firman.

Prinsip pembelajaran matematika saat ini adalah untuk memperbaiki dan menyiapkan aktifitas-aktifitas belajar yang bermanfaat bagi peserta didik yang bertujuan untuk beralih dari mengajar matematika ke belajar matematika.Kerterkaitan peserta didik secara aktif dalam pembelajaran matematika harus disediakannya aktifitas-aktifitas khusus 
sehingga dapat melakukan doing math untuk menemukan dan membangun matematika dengan fasilitas guru.Dengan proses penemuan ini membuat peserta didik lebih memahami konsep.

Pemahaman konsep merupakan salah satu kecakapan atau kemahiran matematika yang diharapkan dapat tercapai dalam belajar matematika yaitu dengan menunjukkan pemahaman konsep matematika yang dipelajarinya, menjelaskan keterkaitan antar konsep dan mengaplikasikan konsep atau algoritma secara luwes, akurat, efisien, dan tepat dalam pemecahan masalah.

Berdasarkan hasil pengamatan yang dilakukan terhadap peserta didik kelas XII SMA Negeri 1 Pangkalan Kerinci diperoleh masalah-masalah yang dihadapi di kelas antara lain: prestasi peserta didik dalam pelajaran matematika relatif masih rendah, rendahnya pemahaman konsep, rendahnya kemampuan pemecahan masalah, dan komunikasi matematis peserta didik yang masih kurang. Prioritas masalah dalam pembelajaran matematika adalah pemahaman konsep matematika. Hal ini disebabkan kemampuan menyelesaikan masalah merupakan tujuan umum pembelajaran matematika, dalam arti pemecahan masalah dapat membantu dalam memecahkan persoalan baik dalam pelajaran lain maupun dalam kehidupan sehari-hari. Selain itu penyelesaian masalah merupakan kemampuan dasar dalam belajar matematika.Agar memiliki pemecahan masalah yang baik, peserta didik harus memiliki pemahaman konsep matematika yang benar.

Beberapa faktor yang menunjukkan pemahaman konsep matematika yang belum benar adalah rendahnya tingkat kemampuan pemecahan masalah. Selain itu, kemampuan peserta didik dalam menyelesaikan soal yang berkaitan dengan materi Dimensi Tiga masih kurang, banyak peserta didik yang mengalami kesulitan untuk memahami maksud soal, merumuskan apa yang diketahui, bahkan proses perhitungan atau strategi penyelesaian masih tidak benar.

Faktor-faktor yang menyebabkan timbulnya masalah-masalah dalam pembelajaran matematika, antara lain; proses pembelajaran belum efektif, suasana belajar mengajar yang kurang kondusif, tingkat keaktifan peserta didik masih kurang, metode pembelajaran yang digunakan guru belum mampu mengaktifkan peserta didik dalam belajar, proses pembelajaran lebih terpusat pada guru serta konsep matematika masih dirasakan abstrak oleh peserta didik. Kondisi pembelajaran di kelas, guru menjelaskan dan peserta didik mendengarkan kemudian mencatat, dan peserta didik mengerjakan soal-soal latihan.

Penulis menyadari bahwa pembelajaran yang diterapkan selama ini masih belum sepenuhnya mampu membantu peserta didik untuk memahami konsep matematika yang bersifat abstrak.Sebagai contoh untuk materi dimensi tiga kelas XII.Kompetensi yang ingin 
dicapai adalah kemampuan untuk menentukan jarak titik dengan titik, titik dengan garis dan sebagainya dalam bangun ruang. Konsep dimensi tiga yang abstrak akan sulit dipahami peserta didik ketika tidak dibantu dengan alat peraga. Untuk itu, penulis berusaha untuk berbenah diri, dengan pendekatan yang diterapkan dan penggunakan alat peraga.Beberapa hal yang pernah dilakukan dalam melakukan perubahan pendekatan pembelajaran tersebut antara lain membentuk peserta didik dalam kelompok, memberikan tugas, mengarahkan peserta didik untuk berdiskusi, meringkas materi pelajaran, presentasi.Akan tetapi, pendekatan yang dilakukan itu masih belum juga secara signifikan membuat peserta didik memiliki pemahaman konsep yang benar.

Suatu model pembelajaran yang dirancang untuk membantu peserta didik dalam memahami konsep jarak dalam dimensi tiga adalah model pembelajaran langsung dengan penggunaan alat peraga bangun ruang dari sumpit.Model pembelajaran langsung menekankan pada penguasaan konsep dan atau perubahan perilaku dengan mengutamakan pendekatan deduktif. Arends (1997) menyatakan: The direct instruction model was specifically designed to promote student learning of procedural knowledge and declarative knowledge that is well structured and can be taught in a step-by-step fashion. Artinya: Model pengajaran langsung secara khusus dirancang untuk mempromosikan belajar peserta didik dengan pengetahuan prosedural dan pengetahuan deklaratif yang terstruktur dengan baik dan dapat diajarkan secara langkah demi langkah. Lebih lanjut Arends (2001) menyatakan: Direct instruction is a teacher-centered model that has five steps: establishing set, explanation and/or demonstration, guided practice, feedback, and extended practice a direct instruction lesson requires careful orchestration by the teacher and a learning environment that businesslike and task-oriented. Artinya: Pengajaran langsung adalah model berpusat pada guru yang memiliki lima langkah: menetapkan tujuan, penjelasan dan/atau demonstrasi, panduan praktek, umpan balik, dan perluasan praktek. Pelajaran dalam pengajaran langsung memerlukan perencanaan yang hati-hati oleh guru dan lingkungan belajar yang menyenangkan dan berorientasi tugas.

Model pengajaran langsung memberikan kesempatan peserta didik belajar dengan mengamati secara selektif, mengingat dan menirukan apa yang dimodelkan gurunya. Oleh karena itu hal penting yang harus diperhatikan dalam menerapkan model pengajaran langsung adalah menghindari menyampaikan pengetahuan yang terlalu kompleks. Di samping itu, model pengajaran langsung mengutamakan pendekatan deklaratif dengan titik berat pada proses belajar konsep dan keterampilan motorik, sehingga menciptakan suasana pembelajaran yang lebih terstruktur.

Guru yang menggunakan model pengajaran langsung tersebut bertanggung jawab dalam mengidentifikasi tujuan pembelajaran, struktur materi, dan keterampilan dasar yang akan 
diajarkan. Kemudian menyampaikan pengetahuan kepada peserta didik, memberikan pemodelan/demonstrasi, memberikan kesempatan pada peserta didik untuk berlatih menerapkan konsep/keterampilan yang telah dipelajari, dan memberikan umpan balik.

Guru yang menggunakan model pengajaran langsung menyampaikan pengetahuan kepada peserta didik menggunakan alat peraga akan membantu peserta didik dalam memahami materi matematika yang bersifat abstrak. Alat peraga dibuat oleh peserta didik, dan digunakan selama pembelajaran dan latihan-latihan soal.

Dari masalah di atas dapat disimpulkan bahwa cara pembelajaran matematika harus diperbaharui guna meningkatkan pemahaman konsep matematika peserta didik, untuk meningkatkan hal tersebut diperlukan sebuah model pembelajaran yang aktif dan inovatif. Salah satunya adalah model pembelajaran langsung dengan menggunakan alat peraga sumpit.

\section{METODE}

Penelitian ini merupakan Penelitian Tindakan Kelas (Classroom Action Research), karena merupakan suatu bentuk kajian yang bersifat refleksif oleh pelaku tindakan. Tindakan yang dilakukan bertujuan untuk meningkatkan kemantapan rasional serta memperbaiki kondisi pembelajaran yang penulis lakukan. Sebagai subjek dalam penelitian ini adalah peserta didik kelas XIIMIPA 2 SMANegeri 1 Pangkalan Kerinci Kabupaten Pelalawan. Penelitian ini dilaksanakan pada Agustus-September tahun pelajaran 2018/2019.

Penelitian akan terdiri dari beberapa siklus, tergantung kepada perkembangan di lapangan. Untuk masing-masing siklus kegiatan akan dirinci menjadi langkah-langkah sebagai berikut : Daur ulang dalam penelitian tindakan diawali dengan perencanaan tindakan, penerapan tindakan, mengobservasi dan mengevaluasi proses dan hasil tindakan, dan melakukan refleksi sebagaimana digambarkan berikut ini : 


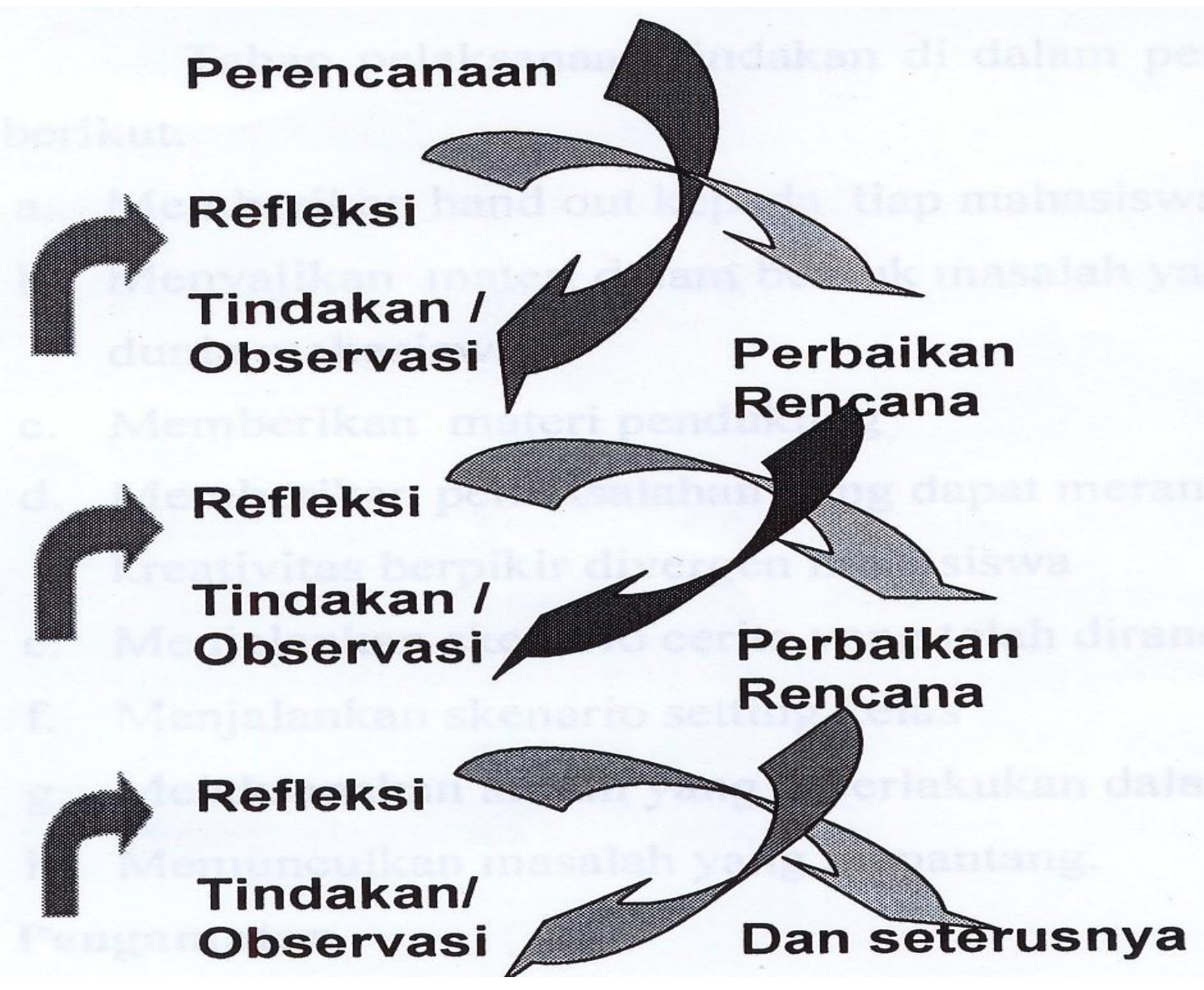

\section{Gambar 1. Spiral Penelitian Tindakan Kelas (Hopkins, 1993)}

Instrumen penelitian yang digunakan pada waktu melaksanakan penelitian dalam upaya mencari dan mengumpulkan data penelitian. Instrumen hasil belajar matematika berupa penilaian harian I (Ujian Blok 1, akhir siklus 1) dan penilaian harian II (Ujian Blok 2, akhir siklus 2). Penulisan instrumen ini berpedoman pada kisi-kisi penulisan soal tes hasil belajar yang mengacu pada indikator yang akan dicapai dan berbentuk uraian. Hasil ulangan harian ini digunakan untuk mengukur ketercapaian indikator tujuan pembelajaran yang diberikan pada akhir pembelajaran. Skor yang diperoleh $=$ tingkat $\mathrm{x}$ bobot. Nilai peserta didik diperoleh dengan perbandingan skor total dengan skor maksimum yang dikonversikan ke dalam skala $0-100$.

Data hasil belajar selanjutnya dianalisis. Analisis data yang dilakukan adalah dengan analisis secara deskriptif. Analisis ini bertujuan untuk melakukan tindakan 
perbaikan yang dilakukan pada siklus selanjutnya. Peserta didik dikatakan telah berhasil memahami materi pembelajaran jika dia mencapai kompetensi minimal $75 \%$.

\section{HASIL DAN PEMBAHASAN \\ Siklus I}

Peneliti dibantu observer melakukan observasi terhadap jalannya proses pembelajaran di kelas dan mencacat semua hasil observasi pada lembar observasi yang telah dipersiapkan sebelumnya. Yang diamati meliputi aktivias guru dan aktivitas peserta didik. Data hasil belajar peserta didik pada penelitian ini dilihat dari skor pemahaman konsep matematika pada tes yang dilaksanakan di akhir siklus I. Penilaian dilakukan sesuai dengan keriteria dan skala yang telah ditetapkan. Hasil belajar peserta didik pada siklus I dapat dilihat pada Tabel 1.

\section{Tabel 1. Hasil Belajar Matematika Siklus I}
Kategori
Jumlah Peserta didik
Persentase

\begin{tabular}{lcc} 
Nilai $\geq 70$ & 23 & 74,19 \\
\hline & & \\
Nilai $<70$ & 8 & 25.81 \\
\hline
\end{tabular}

Jumlah peserta didik yang tuntas pada siklus I sebanyak 23 orang atau 74,19\% untuk KD 3.1, Artinya, jumlah peserta didik yang nilainya di atas KKM sebanyak 74,19\%. Jumlah tersebut belum mencapai keriteria yang diharapkan pada penelitan ini yaitu $75 \%$. Jumlah peserta didik yang belum mencapai KKM relatif masih banyak yaitu 8 orang atau $25,81 \%$, hal ini mengindikasikan perlu perbaikan dalam pembelajaran agar peserta didik lebih memahami pokok bahasan yang diajarkan. Jumlah peserta didik yang memiliki nilai di bawah KKM lebih banyak yaitu 9 orang. Hal ini mengidikasikan harus ada perbaikan untuk pembelajaran selanjutnya. 


\section{Sikulus II}

\section{a. Refleksi}

Sama seperti hanya pada siklus I, peneliti dibantu observer melakukan observasi terhadap jalannya proses pembelajaran di kelas dan mencacat semua hasil observasi pada lembar observasi yang telah dipersiapkan sebelumnya. Yang diamati meliputi aktivias guru dan aktivitas peserta didik.

Data hasil belajar peserta didik pada penelitian ini dilihat dari skor pemahaman konsep matematika pada tes yang dilaksanakan di akhir siklus II. Penilaian dilakukan sesuai dengan keriteria dan skala yang telah ditetapkan. Hasil belajar peserta didik pada siklus 2 dapat dilihat pada Tabel 2.

Tabel 2. Hasil Belajar Matematika Siklus II

\begin{tabular}{ccc}
\hline Kategori & Jumlah Peserta didik & Persentase \\
\hline Nilai $\geq 70$ & 30 & 96,77 \\
\hline Nilai $<70$ & 1 & 3,23 \\
\hline
\end{tabular}

Jumlah peserta didik yang tuntas pada siklus II sebanyak 30 orang atau $96,77 \%$ untuk kompetensi KD 3.1. Artinya, jumlah peserta didik yang nilainya di atas KKM sebanyak 96,77\%. Jumlah tersebut sudah mencapai keriteria yang diharapkan pada penelitan ini yaitu $75 \%$. Jumlah peserta didik yang belum mencapai KKM yaitu 2 orang atau $6,45 \%$, hal ini mengindikasikan pembelajaran sudah mampu meningkatkan hasil belajar matematika dari siklus I.

Dari hasil kegiatan pada siklus I dan II peningkatan hasil belajar matematika peserta didik kelas XII MIPA 2 SMAN 1 Pangkalan Kerinci pada materi Dimensi Tiga diperoleh hasil sebagai berikut:

1. Aktivitas Guru

Aktivitas guru selama pembelajaran dari siklus I ke siklus II menunjukan bahwa guru selalu berupaya dan meningkatkan kinerjadalam melakukan pembelajaran untuk perubahan demi keberhasilan anak didiknya. 
2. Aktivitas Peserta Didik

Aktivitas peserta didik selama proses pembelajaran dari siklus I ke siklus II menunjukan hasil peran peserta didik yang optimal dalam pengelolaan pembelajaran. Dimana peserta didik mempunyai kesadaran untuk mendengarkan dan memperhatikan penjelasan guru dan menyiapkan diri sebelum kegiatan belajar dimulai; peserta didik berdiskusi dan mencari informasi pada aktivitas pembelajaran; peserta didik mempunyai keberanian untuk bertanya dan berpendapat, peserta didik menggunakan alat peraga dan sudah menyesuaikan diri dengan model pembelajaran langsung menggunakan alat peraga sumpit.

3. Hasil Belajar Matematika

Untuk mengetahui hasil belajar matematika peserta didik yang meliputi kompetensi pengetahuan dan keterampilan, peneliti menggunakan tes hasil belajar Matematika.Peningkatan hasil belajar dilihat dari hasil tes evaluasi peserta didik yang diberikan oleh guru untuk dikerjakan oleh peserta didik disetiap akhir siklus. Berikut ini, pembahasan tentang hasil belajar peserta didik yang dilaksanakan pada siklus I dan II.

Tabel 2. Perbandingan Hasil Belajar Siklus I dan Siklus II

\begin{tabular}{|c|c|c|c|c|}
\hline \multirow{2}{*}{ Kategori } & \multicolumn{2}{|c|}{ Jumlah Peserta didik } & \multicolumn{2}{|c|}{ Persentase } \\
\hline & I & II & $\mathbf{I}$ & II \\
\hline Nilai $\geq 70$ & 23 & 30 & 74,19 & 96,77 \\
\hline Nilai $<70$ & 8 & 1 & 25,81 & 3,23 \\
\hline
\end{tabular}


Dari tabel di atas memperlihatkan bahwa hasil belajar kompetensi pengetahuan dan keterampilan peserta didik pada pembelajaran menerapkan model pembelajaran langsung dengan menggunakan alat peraga sumpit mengalami peningkatan dari siklus I ke siklus II. Jumlah peserta didik yang tuntas pada siklus I sebanyak 23 orang atau 74,19dari 31 peserta didik yang ada di kelas XII MIPA 2 SMA Negeri 1 Pangkalan Kerinci. Pada sikus I, hasil belajar yang diperoleh masih kurang dan belum mencapai keriteria yang diharapkan pada penelitian ini yaitu 75\%. Masih banyak peserta didik yang belum menuliskan langkahlangkah pengerjaan soal yang diberikan. Kesalahan pada perhitungan juga terjadi, hal ini menyebabkan nilai siswa tidak sempurna. Setelah dilakukan perbaikan sesuai dengan hasil refleksi yang dilakukan, hasil belajar peserta didik mengalami peningkatan pada siklus II. Dari tabel 2 terlihat bahwa jumlah peserta didik yang tuntas meningkat mencapai 96,77\%.

Dari data tersebut mengindikasikan bahwa sebagian besar peserta didik sudah memperoleh hasil belajar di atas KKM. Peningkatan hasil belajar untuk KD 3.1 dapat dilihat pada Gambar 2.

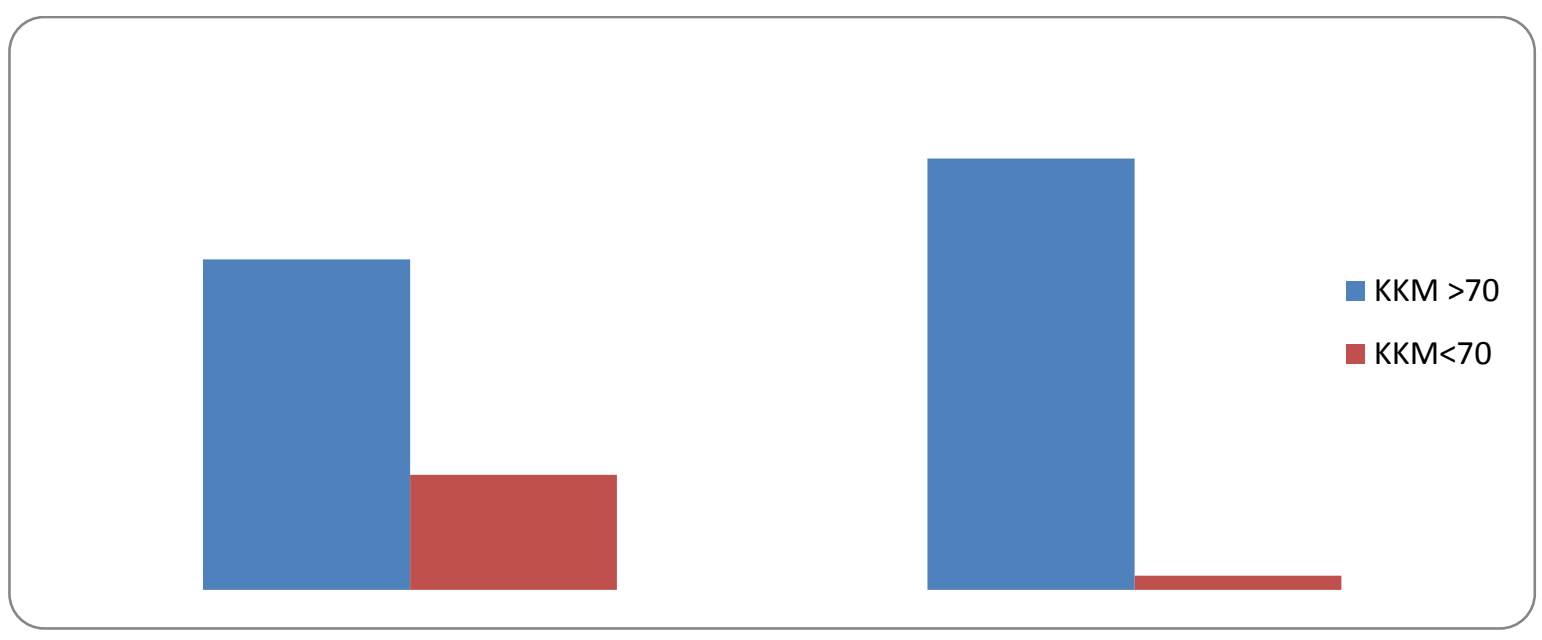

Gambar 2. Perbandingan Hasil Belajar KD 3.1 Siklus I dan Siklus II

Dari Gambar 2 terlihat bahwa terjadi peningkatan hasil belajar peserta didik, dimana pada siklus II menggambarkan bahwa terjadi penurunan persentase peserta didik kategori tidak tuntas dan sebaliknya terjadi peningkatan persentase untuk kategori peserta didik yang tuntas. Meski demikian, pada kemampuan peserta didik sesuai keriteria pemahaman konsep tersebut masih perlu diasah lagi, agar peserta didik terbiasa dalam memahami konsep pelajaran matematika. Nana (2009) mengungkapkan bahwa hasil belajar merupakan kemampuan-kemampuan yang dimiliki peserta didik setelah menerima 
pengalaman belajar. Dengan adanya kegiatan belajar akan menghasilkan perubahan peserta didik atau subjek didik. Perubahan positif pada hasil pembelajaran peserta didik pada penelitian merupakan pertanda meningkatnya kemampuan peserta didik setelah menerima pengalaman belajar pada pembelajaran yang menerapkan model pembelajaran langsung menggunakan alat peraga sumpit.

Model pembelajaran langsung dengan pendekatan modeling atau penggunaan alat peraga membutuhkan penguasaan sepenuhnya terhadap apa yang dibelajarkan (dimodelkan) dan memerlukan latihan sebelum menyampaikan dikelas. Modeling efektif juga menuntut peserta didik mempunyai atensi dan motivasi terhadap perilaku yang dimodelkan. Tanpa hal tersebut proses observasional lainnya yang dibutuhkan dalam pembelajaran langsung dengan alat peraga tidak akan berjalan optimal.

Pembelajaran langsung dirancang untuk penguasaan pengetahuan procedural, pengetahuan deklaratif (pengetahuan faktual) serta berbagai ketrampilan. Pembelajaran langsung dimaksudkan untuk menuntaskan hasil belajar yaitu penguasaan pengetahuan yang distrukturkan dengan baik .

\section{SIMPULAN DAN SARAN}

\section{Simpulan}

Setelah melaksanakan penelitian tindakan kelas dengan menerapkan metode model pembelajaran langsung menggunakan alat peraga sumpit pada mata pelajaran matematika pokok bahasan dimensi tiga di kelas XII MIPA 2 SMA Negeri 1 Pangkalan Kerinci, jumlah peserta didik yang tuntas meningkat untuk KD 3.1 sebesar 22,58\% atau mencapai 96,77\% peserta didik yang berada di atas KKM. Sedangkan untuk KD 4.1 peningkatan dari siklus I ke siklus II sebesar 22,58 \% atau mencapai 93,55\% peserta didik berada di atas KKM. Berdasarkan uraian pencapaian hasuil belajara dapat diperoleh kesimpulan bahwa penerapan metode model pembelajaran langsung menggunakan alat peraga sumpit dapat meningkatkan hasil belajar peserta didik.

\section{Saran}

Berdasarkan hasil penelitian tindakan kelas dengan menerapkan pembelajaran langsung menggunakan alat peraga sumpit pada mata pelajaran matematika pokok bahasan dimensi tiga kelas XII MIPA 2 SMA Negeri 1 Pangkalan Kerinci pada tahun pelajaran 2018/2019, dapat dikemukakan saran-saran sebagai berikut :

1) Dalam menerapkan pembelajaran dengan pembelajaran langsung menggunakan alat peraga sumpit sebaiknya guru membuat perencanaan yang matang sehingga pembelajaran berjalan secara sistematis. Perencanaan yang matang menjadikan 
pemanfaatan waktu berjalan efektif. Pembelajaran yang optimal akan mempengaruhi hasil belajar.

2) Alat peraga yang digunakan harus kokoh sehingga ketika pendemontrasian penggunaan alat peraga tidak mengalami kendala. Sebaiknya sumpit yang digunakan diganti dengan kawat.

3) Memotivasi siswa yang berkemampuan tinggi untuk membantu teman-temannya mengecek kesalahan-kesalahan menghitung yang dilakukan sehingga hasil belajar matematika lebih baik lagi serta diskusi berjalan sesuai dengan yang direncanakan.

\section{DAFTAR PUSTAKA}

Abbas, Nurhayati. ( 2008). Meningkatkan Hasil Belajar Matematika Peserta didik Melalui Model Pembelajaran Berbasis Masalah Dengan Penilaian Portofolio di SMPN 10 Kota Gorontalo. Program Studi Pendidikan Matematika Pascasarjana: UNESA.

Arends, Richard. (2008). Learning to Teach. Jakarta: Pustaka Pelajar.

Arikunto, Suharsimi. (2010). Penelitian Tindakan Kelas. Jakarta: Penerbit Bumi Aksara.

Baharuddin dkk. (2007). Teori Belajar dan Pembelajaran. Yogjakarta: Penerbit Ar-Ruzz Rineka Cipta.

Barret, T. (2005). Understanding Problem Based Learning. Handbook of Enquiry and Problem-Based Learning. Irish Case Studies and International Perspectives. Aishe Readings.

Fitriani, N. (2012). Penerapan Pendekatan Pendidikan Matematika Realistik Secara Berkelompok untuk Meningkatkan Kemampuan Pemecahan Masalah Matematis dan Self Confidence Peserta didik SMP. Tesis. UPI. Tidak Diterbitkan.

Ibrahim, Muslimin dan Nur. 2000. Pembelajaran Berdasarkan Masalah. Surabaya: UNESA.

Kyeong Ha, Roh. (2003). Problem-Based Learning in Mathematics. Dalam Eric Digest. Eric Identifier: EDO-SE-03-07. Online. http://www.ericdigest.org.

Muiz, D.A. (2005). Pembelajaran Berbasis Masalah (Problem Based Learning). http://file.upi.edu/Direktori/KDtasikmalaya/dindin_abdul_muiz_lidinillah. Pdf.

Nana, S. 2010. Dasar-dasar Proses Belajar. Bandung: Sinar Baru.

Peraturan Menteri Pendidikan Nasional Nomor 22. 2006. BSNP. Jakarta

PISA. 2009. Canadian Results of the OECD PISA Study. Online. Tersedia: http://www.cmec.ca/Publications/Attachments/254/PISA2009-can-report.pdf. 
Ruseffendi. (2006). Pengantar Kepada Membantu Guru Mengembangkan Kompetensi

Dalam Pengajaran Matematika Untuk Meningkatkan CBSA. Bandung: Penerbit Tarsito.

Sudjana, Nana. (2009). Dasar-dasar Proses Belajar Mengajar. Bandung: Penerbit Sinar Baru Argensindo.

Suherman. (2001). Strategi Pembelajaran Matematika Kontemporer. Bandung: UPI.

Sumarmo, Utari. (2010). Berfikir dan Disposisi Matematik : Apa, Mengapa, dan Bagaimana Dikembangkan pada Peserta Didik. Bandung: FMIPA UPI.

Trianto. 2009. Model Pembelajaran Terpadu dalam Teori dan Praktek. Surabaya: Pustaka Ilmu. 